\title{
Learning Styles Analysis based on Pattern Recognition Techniques
}

\author{
Anilu Franco-Arcega, María J. Gutiérrez-Sánchez, and \\ Alberto Suárez-Navarrete \\ Universidad Autónoma del Estado de Hidalgo, \\ Instituto de Ciencias Básicas e Ingenierías, Mineral de la Reforma, Hidalgo, \\ Mexico \\ anifranco6@gmail.com, chuysy79@hotmail.com, betucos@gmail.com \\ http://www. uaeh.edu.mx
}

\begin{abstract}
This paper presents an analysis of different learning styles observed in a group of college freshmen. Recognizing relevant aspects of each style provides aid in the planning of actions that could reduce dropouts and increase the academic performance of first-year students in colleges. To accomplish this study an assessment tool was devised and implemented applying techniques of clustering and measurement of the attributess informational weight. The results showed distinctive attributes that allow them to be classified within five groups (learning styles) that were labeled according to the Felder-Silverman model, and from said groups the visual as well as the active style appear dominant in the case study.
\end{abstract}

Keywords: Clustering, informational weight, learning styles

\section{Introduction}

The Pattern Recognition Techniques (PR) allows us to acquire valuable knowledge from data sets that store some information of some specific context. They can be used to automate the speech recognition, fingerprint identification, social problems analysis, or in the prediction of new outcomes in almost any environment, weather it is related to banking, educational, financial, chemical, among others [5]. This discipline can emulate the human ability to describe the behavior of data using automated methods.

There are several PR tasks that can be applied to solve a problem, especially those that solve prediction problems (classification) and description (clustering). The first ones refer to the allocation of a new object to a known class, i.e. the set of training data is divided into a finite number of classes, which can be identified by patterns of behavior, and through these patterns define the class which a new object belongs to. On the other hand, the descriptive problems include mainly those without an a priori classification, in this case the goal is to find a partition 
that allows to characterize the objects in the data set into groups with similar behavior [12].

As a result, the PR has been successfully applied to several areas, including agriculture, astronomy, biology, economics, geology, medicine, among others. In this paper, the addressed issue is applying these intelligent techniques to education. One of the highlights of this environment is to provide knowledge to students in a way they understand all concepts and tools teached in class. In order to achieve this goal it is necessary that teachers know the learning styles of their students [9], since some absorb knowledge through traditional learning strategies (readings, concept maps, etc.), but others need different strategies to get what is transmitted by teachers.

There have been several instruments and conducted studies to understand and classify the different learning styles of students, which allows to know and use different methodologies to suit their characteristics, such as the one made at the Universidad Tecnológica de Perú [2] where they found through a statistical analysis that the divergent style is prevalent among students of that institution. Furthermore, the Peruvian University [10], used as an instrument The Honey - Alonso Learning Styles Questionnaire (CHAEA) and Roman JM, Learning Strategies Questionnaire (ACRA), moreover a relationship between learning styles and strategies of their students was found by applying a statistical analysis, considering their academic performance as a fundamental part.

Meanwhile, Mara del Carmen Aguilar Rivera [1] indicates that the relationship between styles and learning strategies in students entering the university explains theories and concepts with regard to measuring instruments used, as the obtained results are analyzed and the related statistical application of the questionnaires used. To find this relationship the Cronbach's Alpha estimate was used, which is interpreted as a weighted average calculated from the variances or correlations of the study variables. The results focus only present correlations between different learning styles and strategies.

It is noteworthy that building a model of learning styles, it allows the classification of students according to the way on how they receive and process information, as shown in "Minería de datos para descubrir estilos de aprendizaje" Elena Durán and Rosanna Costaguta [6], in which they also indicate three stages to develop this work: pre-processing, data mining and post-processing. The aim of this study was to identify the prevalent learning style in a group of college students, but not to find their behavior patterns.

The recognition of various styles in the way of learning indicates the existence of different individual, social and cultural factors in the ways in which the student interacts with the acquisition of knowledge [13], [4]. Hence the interest of this research is, performing it with the help of professionals in education, to organize and characterize groups that result after completing the corresponding surveys.

The application of pattern recognition techniques serves as a tool for identifying learning styles in students of first semester of the Computer and Electronics Academic Area (AACyE) of the Hidalgo State Autonomous University (Universidad Autónoma del Estado de Hidalgo) (UAEH). Its data was obtained from a 
questionnaire designed to identify the factors that may influence the academic performance, in order to obtaining information to improve decision making and, from it, develop strategies to improve the school performance.

\section{Study Case and Employed Methodology}

This section introduces the process that was conducted to collect data allowing the characterization of students in groups according to different learning styles. As well as, the description of data, and the used pattern recognition procedure, are shown.

\subsection{Preparation of Data}

In order to recognize what learning styles are predominant in college freshmen, we chose to apply a questionnaire that serves as an assessment instrument of their study habits and preferences in their learning process, so we can pass on this knowledge on to teachers allowing the use of specific learning strategies.

The questionnaire was developed in conjunction with an expert of the Academic Area of Educational Sciences (Área Académica de Ciencias de la Educacin) $\mathrm{UAEH}$, based on three different evaluation tools:

1. Questionnaire to university students by Martha Artunduaga Murillo [3]

2. Learning Styles Test by David Kolb [8]

3. Abbreviated ACRA scale to university students by Jesús de la Fuente Arias et. al [7]

The overall purpose of these questionnaire is to evaluate the academic performance in order to identify strategies to improve performance and reduce dropout rates at universities.

Abbreviated ACRA is a self-instrument, which is inspired by the principles of cognitive information processing, allowing quantitatively evaluate various learning strategies used by students. In the study phases it handles the acquisition, encoding, retrieval and information support.

The other Artunduaga's measurement scale, focuses primarily on academic performance and dropouts, emphasizing on basic skills and students abilities to organize their time, to manage and implement a study method to receive and organize information. It also considers the degree of motivation and satisfaction provided by their studies, their capacity of future planning, academic and selfconcept as well as their skills.

The final questionnaire is composed by 37 questions (considered as attributes) and was applied to 165 students in the first semester of the Bachelor in Computer Science (94 students), Electronic Engineering (28 students) and Telecommunications Engineering (43 students) of AACyE at the Institute of Basic Sciences and Engineering UAEH (Instituto de Ciencias Básicas e Ingeniería UAEH).

From these 165 students, 37 were women and 128 men between 17 and 25 years old. Once the surveys were applied, the results were captured in a database 
that would build the minable view for processing. Since it is possible to choose more than one answer for each question a set of keys was made to identify the possible answers of the students

\subsection{Aplicacition of Pattern Recognition Process}

To carry out the processing of the data, obtained in the previous section, the modeling process shown in [11] which involves the participation of specialists in the area of application and pattern recognition specialists, was applied. This process is shown in Figure 1, where it can be observed how a real situation is modeled up to the solution of the problem, including a pattern recognition model which allows us to find hidden knowledge in the data. In this particular case, it is a characterization of the students according to learning styles they use in their training.

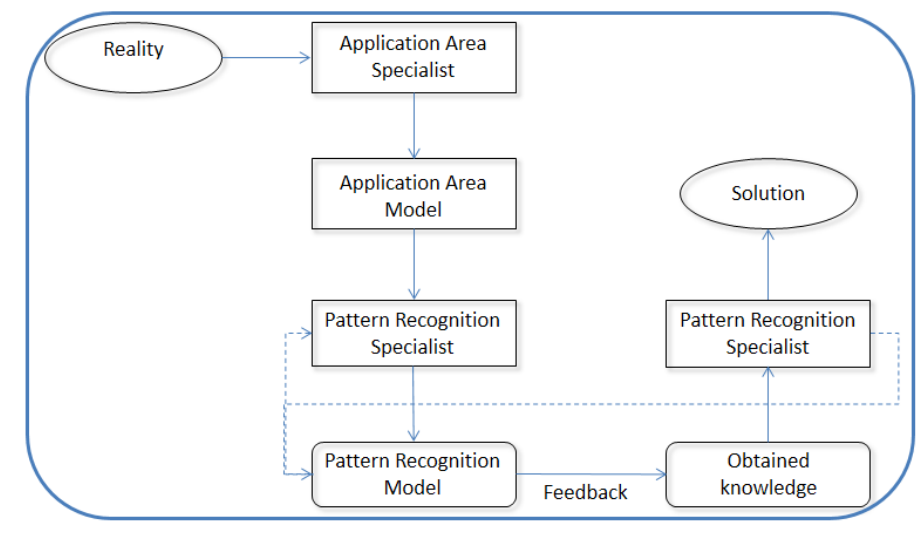

Fig. 1. Pattern Recognition Process

The role every specialist must follow in the pattern recognition and application areas were identified, so that each one contributes effectively to the solution of the problem. With the help of the expert in education, the model was found in the application area as a set of pre-selected, integrated and prepared data (using the data described in Section 2.1). This model allows access to information using pattern recognition techniques. The chosen techniques are in the family of unsupervised classification, since the aim is to find the partition on which the data is grouped making it possible to characterize the obtained groups. Finally, this characterization will help to recognize learning styles employed by the surveyed students. Figure 2 presents the specific model of pattern recognition for this case study. 


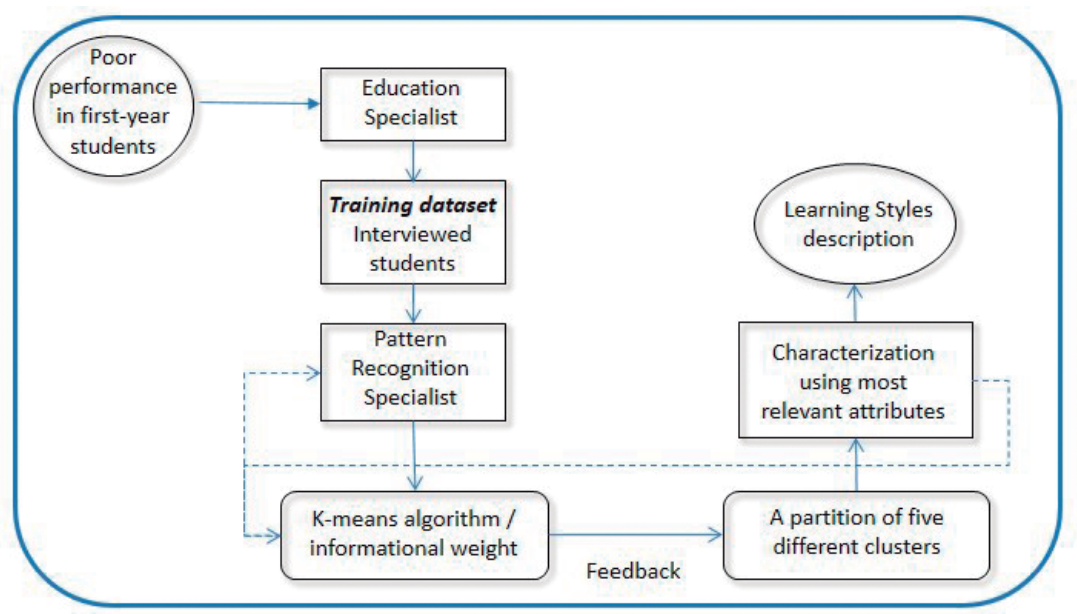

Fig. 2. Pattern Recognition Process applied to the analysis of learning styles

\section{Experimental Results}

The following experiments were performed using the Weka software version 3.6.12. The first step was applying the Simple K-Means algorithm to generate the groups that represent the freshmen learning styles. The parameter $k$ was set to five, given Felder and Silverman's [6] model, where the learning styles recognized are sensory, visual, active, sequential and inductive.

The distribution of samples attained by the 165 students surveyed into the five groups, is shown in Table 1; where it can be noticed the two learning styles that are predominant in this sample.

Table 1. K-Means results

\begin{tabular}{|l||c|c|c|c|c|}
\hline Cluster & $\mathbf{0}$ & $\mathbf{1}$ & $\mathbf{2}$ & $\mathbf{3}$ & $\mathbf{4}$ \\
\hline Number of instances & 28 & $\mathbf{5 5}$ & 18 & 13 & $\mathbf{5 1}$ \\
\hline Percentage & 17 & $\mathbf{3 3}$ & 11 & 8 & $\mathbf{3 1}$ \\
\hline
\end{tabular}

Subsequently, in order to determine which are the most influential variables in this study, the information of the variables that describe the behavior of the surveyed students was measure. This measure helped choose the most representative variables to build the characterization of each group, applying Weka's Information Gain Ranking Filter method, the attained results are shown in Table 2.

The first ten variables that charted value greater than 0.45 were used as reference and from the most common findings, the characterization of each group 
Anilu Franco-Arcega, María J. Gutiérrez-Sánchez, and Alberto Suárez-Navarrete

Table 2. Information Gain Ranking Filter results

\begin{tabular}{|c|c|c||c|c|c|}
\hline Position & Attribute & Ranking & Position & Attribute & Ranking \\
\hline \hline $\mathbf{1}$ & 21 & 0.6365 & 20 & 32 & 0.2305 \\
$\mathbf{2}$ & 18 & 0.5621 & 21 & 8 & 0.2240 \\
$\mathbf{3}$ & 34 & 0.5619 & 22 & 6 & 0.2111 \\
$\mathbf{4}$ & 20 & 0.5375 & 23 & 7 & 0.1974 \\
$\mathbf{5}$ & 22 & 0.5128 & 24 & 10 & 0.1745 \\
$\mathbf{6}$ & 24 & 0.5033 & 25 & 37 & 0.1705 \\
$\mathbf{7}$ & 33 & 0.4978 & 26 & 31 & 0.1670 \\
$\mathbf{8}$ & 19 & 0.4884 & 27 & 15 & 0.1309 \\
$\mathbf{9}$ & 27 & 0.4560 & 28 & 5 & 0.1177 \\
$\mathbf{1 0}$ & 30 & 0.4544 & 29 & 1 & 0.1100 \\
11 & 26 & 0.4383 & 30 & 2 & 0.0428 \\
12 & 28 & 0.4344 & 31 & 16 & 0.0395 \\
13 & 11 & 0.3832 & 32 & 29 & 0.0287 \\
14 & 25 & 0.3824 & 33 & 4 & 0.0124 \\
15 & 23 & 0.3174 & 34 & 3 & 0.0000 \\
16 & 17 & 0.3133 & 35 & 13 & 0.0000 \\
17 & 9 & 0.2851 & 36 & 14 & 0.0000 \\
18 & 36 & 0.2614 & 37 & 35 & 0.0000 \\
19 & 12 & 0.2342 & & & \\
\hline
\end{tabular}

was built. Table 3 shows these descriptions, alongside the general description given by Felder and Silverman of each learning style.

Based in the comparison between the description obtained and the description given by these authors, and with the help of an expert in the subject, it was possible to label each group as one of the learning styles aiding in the identification of the different types of college freshmen. Making use of these descriptions teachers could develop strategies to improve the students academic performance.

\section{Conclusions}

The application of PR techniques in different areas has been relevant to solving real problems. In particular, in the area of education, to find knowledge on information provided by students, faculty and staff, it allows to develop different strategies for an efficient decision making.

The development of this work allowed to determine patterns of behavior that recognize learning styles (sensory, visual, active, sequential and inductive) among freshmen in a particular study case, whether the students are from the area of Computing and Electronics of the University of the State of Hidalgo (Computación y Electrónica de la Universidad Autónoma del Estado de Hidalgo). A survey was conducted among the newly admitted freshmen and once this data was prepared, a partition was obtained from it through the K-Means 
Table 3. Description of the different learning styles

\begin{tabular}{|c|c|c|c|}
\hline Learning style & $\begin{array}{l}\text { Definition (Felder and Silver- } \\
\text { man) }\end{array}$ & Obtained cluster & $\begin{array}{l}\text { Characterization obtained } \\
\text { from the experiments results }\end{array}$ \\
\hline Sequential & $\begin{array}{l}\text { Sequential learners follow linear } \\
\text { reasoning processes when solving } \\
\text { problems. Global learners make } \\
\text { intuitive leaps and may be un- } \\
\text { able to explain how they came up } \\
\text { with solutions }\end{array}$ & 0 & $\begin{array}{l}\text { Are observant people who reason } \\
\text { and mentally prepare what to } \\
\text { say or write. Best learn through } \\
\text { practice. In order to memorize } \\
\text { makes use of visual tools such as } \\
\text { concept maps }\end{array}$ \\
\hline Visual & $\begin{array}{l}\text { Remember what they see: pic- } \\
\text { tures, diagrams, flow charts, } \\
\text { time lines, films, demonstrations. } \\
\text { Rather attain information by lis- } \\
\text { tening }\end{array}$ & 1 & $\begin{array}{l}\text { They are reserved and quiet, } \\
\text { learn best when they observe } \\
\text { carefully. When faced with } \\
\text { a problem they generate } \\
\text { approximate answers by } \\
\text { inferring from the knowledge } \\
\text { they possess. Their study } \\
\text { habits mainly include the } \\
\text { use of processing strategies } \\
\text { such as drawings, graphics and } \\
\text { images, to establish relationships } \\
\text { between the content of their } \\
\text { subjects }\end{array}$ \\
\hline Inductive & $\begin{array}{l}\text { Induction is the natural human } \\
\text { learning style observe the world } \\
\text { around them and draw infer- } \\
\text { ences. State the governing prin- } \\
\text { ciples and work down to the ap- } \\
\text { plication }\end{array}$ & 2 & $\begin{array}{l}\text { They are rational and reserved, } \\
\text { who work hard to get things } \\
\text { done. Analyze by dividing things } \\
\text { into parts and generate an ap- } \\
\text { proximate answer by inferring } \\
\text { from the knowledge they possess. } \\
\text { Learn best through observation }\end{array}$ \\
\hline Sensory & $\begin{array}{l}\text { Learn and memorize facts, they } \\
\text { are practical and careful. Prefer } \\
\text { principles and theories, like inno- } \\
\text { vation and dislike repetition }\end{array}$ & 3 & $\begin{array}{l}\text { They are open people and re- } \\
\text { sponsible that learn best when } \\
\text { they rely on their logical think- } \\
\text { ing, who make use of ratio- } \\
\text { nal theories and learning strate- } \\
\text { gies to memorize by repetition, } \\
\text { mnemonics, pictures, summaries } \\
\text { and mind maps. When faced } \\
\text { with a problem they generate ap- } \\
\text { proximate answers by inferring } \\
\text { from the knowledge they possess }\end{array}$ \\
\hline Active & $\begin{array}{l}\text { Active experimentation involves } \\
\text { doing something in the external } \\
\text { world with the information. Re- } \\
\text { flective observation involves ex- } \\
\text { amining and manipulating the } \\
\text { information introspectively }\end{array}$ & 4 & $\begin{array}{l}\text { They are rational and open } \\
\text { minded people who mentally pre- } \\
\text { pare what to say or write. They } \\
\text { learn through reasoning and } \\
\text { practice. Repetition, mnemon- } \\
\text { ics and summaries are common } \\
\text { learning strategies }\end{array}$ \\
\hline
\end{tabular}

algorithm. These results were used to analyze the set of variables that describe these students, which allowed us to identify the characteristics that best define each learning style.

From the characterizations found in this sample it was observed that the visual and active ones are dominant learning styles. These results will generate proposals to adapt different teaching styles of teachers in this area, in regards to the dominant learning styles of the student population, without neglecting the others.

As future work it intends to apply other clustering algorithms and automatically choose the best among them, in order to find the relationship between the 
model of Felder-Silverman and others. Besides, we consider to apply association rules methods to compare the obtained characterization in this work and the set of rules that describe the obtained clusters.

\section{References}

1. Aguilar Rivera, M.: Estilos y estrategias de aprendizaje en jóvenes ingresantes a la universidad. Revista de Psicología 28(2), 207-226 (2010)

2. Arias Gallegos, W.: Estilos de aprendizaje en estudiantes universitarios y sus particularidades en función de la carrera, el género y el ciclo de estudios. Revista Estilos de Aprendizaje 8(4), 112-135 (2011)

3. Artunduaga Murillo, M.: Variables que influyen en el rendimiento académico en la Universidad. Editor Departamento MIDE, Universidad Complutense de Madrid (2008)

4. Cassidy, S.: Learning styles: An overview of theories, models, and measures. International Journal of Experimental Educational Psychology 24(4), 419-444 (2004)

5. Duda Richard, O., Hart Peter, E., Stork David, G.: Pattern Classification. John Wiley and Sons, USA (2001)

6. Duran, E., Costaguta, R.: Minería de datos para descubrir estilos de aprendizaje. Revista Iberoamericana de Educación 42(2), 1-10 (2007)

7. Fuentes-Árias, J., Justicia-Justicia, F.: Escala de estrategias de aprendizaje acraabreviada para alumnos universitarios. Revista Electrónica de Investigación Psicoeducativa y Psicopedagógica 1(2), 140-158 (2003)

8. Kolb, D.: Psicología de las organizaciones: experiencia. Prentice Hall, México (1984)

9. Kolb, A, Y., Kolb, D.: Learning styles and learning spaces: enhancing experiential learning in higher education. Academy of Management Learning and Education 4(2), 193-212 (2005)

10. Loret de Mola Garay, J.: Estilos y estrategias de aprendizaje en el rendimiento académico de los estudiantes de la universidad peruana. Revista Estilos de Aprendizaje 8(4), 149-184 (2011)

11. Ruiz-Shulcloper, J., Guzmán Arenas, A., Martínez-Trinidad, J.: Enfoque Lógico Combinatorio al Reconocimiento de Patrones I, Selección de Variables y Clasificación Supervisada. IPN, México (1999)

12. Marques de Sa, J.P.: Pattern Recognition: Concepts, Methods, and Applications. Springer-Verlag Berlin Heidelberg, New York, USA (2001)

13. Willingham, D., Hughes, E., Dobolyi, D.: The scientific status of learning styles theories. Teaching of Psychology 42(3), 266-271 (2015) 